\title{
Knowledge and attitudes towards genetic testing in those affected with Parkinson's disease
}

\author{
Tracey M Scuffham • Aideen McInerny-Leo • \\ Shu-Kay Ng • George Mellick
}

Received: 26 February 2013 / Accepted: 28 August 2013 / Published online: 10 September 2013

(C) Springer-Verlag Berlin Heidelberg 2013

\begin{abstract}
Advances in genetic tests provide valuable information for clinicians and patients around risks and inheritance of Parkinson's Disease (PD); however, questions arise whether those affected or at risk of PD will want genetic testing, particularly given that there are no preventive or diseasemodifying therapies currently available. This study sought to determine knowledge and attitudes toward genetic testing for those affected with PD. A cross-sectional study was undertaken using a standardized questionnaire with six multi-choice genetic knowledge and 17 multi-choice attitude items. Participants were selected from a registry of people affected with PD living in Queensland, Australia. Half of the selected index cases had a family history of PD. Ordinal regression was used to evaluate the association between support for genetic
\end{abstract}

Electronic supplementary material The online version of this article (doi:10.1007/s12687-013-0168-7) contains supplementary material, which is available to authorized users.

T. M. Scuffham $(\bowtie)$

Genetic Health Queensland, Level 4, Building C28, Herston,

4029 Brisbane, QLD, Australia

e-mail: tscuffham@internode.on.net

A. McInerny-Leo

Diamantina Institute, University of Queensland, Brisbane, Australia

S.-K. Ng

School of Medicine and Griffith Health Institute, Griffith University, Griffith, Australia

G. Mellick

Department of Neurology, Princess Alexandra Hospital, Brisbane, Australia

G. Mellick

Eskitis Institute for Cell and Molecular Therapies, Griffith

University, Brisbane, Australia testing and demographic, knowledge, and other attitudinal factors. The level of genetic knowledge was relatively low (37\% correct responses). The vast majority supported diagnostic testing (97\%) and $90 \%$ would undertake a genetic test themselves. Support for predictive was lower $(78 \%)$ and prenatal genetic testing had the least support (58\%). Benefits of testing were identified as the ability to know the child's risk, seek therapies, and helping science with finding a cure. Concerns about genetic testing included potential emotional reactions and test accuracy. Genetic knowledge was not significantly associated with attitudes towards genetic testing. Patients with PD have strong interest in genetic testing for themselves with support for diagnostic testing but less support for predictive and prenatal testing. Genetic knowledge was unrelated to testing attitudes.

Keywords Genetic counseling · Genetic testing · Australia · Attitudes $\cdot$ Knowledge $\cdot$ Parkinson's disease

\section{Introduction}

Parkinson's disease (PD) is a debilitating chronic disorder affecting upwards of 30,000 Australians (Peters et al. 2006). In European populations it is reported to affect between 108 and 257 per 100,000 population (von Campenhausen et al. 2005). It is ranked among the top 20 causes of disability in Australia (Australian Institute of Health and Welfare 2008).

PD is generally considered an idiopathic disease. However, some familial clusters have been identified with apparent Mendelian inheritance patterns. It is known that offspring of an affected parent have a two- to three-fold risk of also being affected with PD compared with population norms (Autere et al. 2000; Sveinbjornsdottir et al. 2000; Sellbach et al. 2006). In recent years, a genetic basis for the disease has been shown 
particularly in patients with young age of onset. Genes identified as directly associated with PD include $S N C A, P R K N$, PINK1, DJ-1, and LRRK2. There are diverging estimates of the contribution of mutations in these genes to PD, with estimates ranging from less than $5 \%$ (Pankratz and Foroud 2007 ) to about $10 \%$ of all cases of PD (de Lau and Breteler 2006). However, the frequency of some forms of primary genetic parkinsonism is very population dependent; for example $L R R K 2$ parkinsonism accounts for approximately $40 \%$ of familial PD in Tunisians and $<3 \%$ in North Americans (Ishihara et al. 2007). In Queensland, approximately $7 \%$ of early onset PD cases are associated with a known genetic mutation (Mellick et al. 2009). Nevertheless, the vast majority of PD occurs in the absence of a family history and even for most familial clusters the genes responsible for the phenotype remain unidentified.

Identification of disease-causing genes has generated opportunities for genetic testing of PD to confirm diagnosis of the disease or determine whether people are at risk of PD. While the use of genetic tests may provide valuable information for clinicians and patients, the question arises whether those affected or at risk of PD will want genetic testing, particularly given that there are no preventive or disease-modifying therapies currently available. However, if they are found to carry a PDassociated mutation, they can inform their offspring of the potential risk. It has been postulated that people's attitudes towards genetic testing are determined by their knowledge and pre-conceived notions about genetics (Quaid et al. 1989; Tan et al. 2007). Thus, factors, such as the knowledge of genetics and attitudes people have towards genetic testing, may have a substantial role in determining uptake of genetic testing for PD. The aim of this study was to assess the knowledge of genetics and the attitudes toward genetic testing of patients affected with PD. A secondary aim was to identify the determinants of attitudes towards genetic testing.

\section{Methods}

\section{Study design}

A cross-sectional postal survey of patients diagnosed with PD was undertaken using a standardized questionnaire. The questionnaire was constructed by drawing on items used in other published studies after an extensive literature review on adult onset neurodegenerative disorders (Quaid et al. 1989; Tan et al. 2007; Evers-Kiebooms et al. 1987; Mastromauro et al. 1987; Quaid 2999). The questionnaire contained 41 items in four sections: demographic information, knowledge about genetics and PD, attitudes about genetic testing for PD, and genetic information services (see supplementary information).

The knowledge items were made up of one open-ended question asking the cause of PD (and was used as a priming question to encourage participants to think about their knowledge of PD), a self-perceived genetic knowledge item, five previously validated multiple-choice items on genetic knowledge about PD (Tan et al. 2007) and an additional item on genetics in general. Responses to these questions were "agree", "disagree", and "don't know".

The attitude section comprised 17 multiple choice questions around genetic testing. Three questions elicited attitudes around whether diagnostic, predictive, and prenatal testing should be made available, and whether the participant would consider having a genetic test themselves. The remaining questions in this section described various positive and negative reactions to genetic test results with four response options of: "strongly agree", "agree", "disagree", or "strongly disagree" (Lerman et al. 1995).

\section{Recruitment of participants}

Subjects were drawn from the Queensland Parkinson's Project (QPP). The QPP is a collaborative research study cohort of over 3,000 community dwelling Queenslanders all with PD, recruited on a rolling basis since 2005 , who have agreed to participate in research into PD. The QPP sample were recruited at the time of diagnosis through a network of neurologists with specialist expertise in movement disorders (Sutherland et al. 2009). All PD patients were diagnosed according to the United Kingdom Brain Bank criteria by neurologists. Each subject had undergone a Mini-Mental State Exam within the last 2 years, and achieved a score greater than 23 (Folstein et al. 1975). No participants had previously undergone genetic testing or counseling for PD and as their blood samples were for research purposes only, no results had been conveyed to participants.

Two samples were drawn from the QPP database; one sample was all those who had previously reported a family history of PD ( $n=144$, mean age 68.1 years (SD, 9.0), $60.4 \%$ male); the second sample, approximately equal in numbers and without a reported family history, was randomly drawn from the remaining subjects and matched on age and gender $(n=146$, mean age 70.1 years (SD, 8.9), $61.0 \%$ male). There were no statistical differences in gender $(p=0.977)$ or age ( $p=$ 0.058 ) between these groups.

\section{Data analysis}

Data were analyzed using SPSS v20 (IBM SPSS for Windows v20. (SPSS Inc and Chicago 2011)). Responses to knowledge items were dichotomized into correct and incorrect/don't know responses for further analysis. Responses to attitude items were dichotomized into "agree/strongly agree" and "disagree/strongly disagree".

To better understand the determinants of support for genetic testing, multivariate analysis using ordinal regression was 
undertaken (Norušis 2012). Four genetic testing outcome variables were used in independent models: support for diagnostic testing, support for predictive testing, support for prenatal testing, and whether the respondent would undergo a genetic (diagnostic) test themselves. Ordinal regression was adopted as the dependent variables, and many of the explanatory variables (specifically the attitude items), had four ordinal levels of response. As the cumulative probability for lower ordinal levels (such as "strongly agree" and "agree") is high, the negative $\log -\log$ link was selected. This link function also provided a better fit for the proportional odds assumption in the ordinal regression models (Brant 1990), where the assumption was formally tested using the "Test of Parallel Lines" function in SPSS.

Explanatory factors included in all four regression models were the correct/incorrect responses to the knowledge items, all demographic factors and the remaining attitude items. A stepwise approach was used where significant predictors (at $p \leq$ 0.10 ) from univariate analyses (Appendix A) were entered into the multivariate model; the predictor with the largest $p$ value (least significant) was removed from the model. This step is repeated until the final models were reached. Goodness of fit of final ordinal regression models was assessed using the deviance measure comparing the observed and expected frequencies. The strength of the association between dependent and explanatory variables was measured using the Cox and Snell R (von Campenhausen et al. 2005) statistic. The referent for the testattitude items were set to strongly disagree; and the estimated coefficients from the ordinal regression were presented so that a positive coefficient is interpreted as indicating greater support for the test and a negative coefficient indicates less support for the test (i.e., more likely to disagree with the test). Coefficients for constants and demographic factors are interpreted in the usual manner.

\section{Results}

Questionnaires were mailed to 290 subjects; 18 subjects had an invalid address, were in hospital, or had died. Of the remaining 272 sampled, 187 completed questionnaires were received giving an overall response rate of $68.8 \%$ (no family history, 88/136, 64.7 \%; with family history, 99/136, $72.8 \%$ ). The mean age of respondents was 68.4 (SD 8.7) years and $62 \%$ were male (Table 1 ). The mean age of those with and without a family history was 67.5 years (SD 11.2) and 70.2 (SD 8.1), respectively $(p=0.060)$, and 62.2 and $62.5 \%$ were male in each group $(p=0.972)$. The majority were married with a median of three children, and almost half had undertaken some form of training following high school education. Almost half of the respondents reported at least one relative with PD. Assistance to complete the questionnaire was
Table 1 Demographic characteristics of the sample

\begin{tabular}{|c|c|c|c|}
\hline & & No. & \\
\hline \multirow[t]{2}{*}{ Age } & Mean (years) & 187 & 68.4 years \\
\hline & SD & & 8.7 years \\
\hline \multicolumn{4}{|c|}{$\operatorname{Sex}(n=187)$} \\
\hline & Male & 116 & $62.0 \%$ \\
\hline & Female & 71 & $38.0 \%$ \\
\hline \multicolumn{4}{|c|}{ Married $(n=187)$} \\
\hline & Married/de-facto & 152 & $81.3 \%$ \\
\hline & Separated/divorced/ widowed & 31 & $16.6 \%$ \\
\hline & Single/never married & 4 & $2.1 \%$ \\
\hline \multicolumn{4}{|c|}{ Education $(n=187)$} \\
\hline & Did not go to school & 1 & $0.5 \%$ \\
\hline & Left school $<16$ years & 47 & $25.1 \%$ \\
\hline & Left school $\geq 16$ years of age & 47 & $25.1 \%$ \\
\hline & Trade cert./apprenticeship & 45 & $24.1 \%$ \\
\hline & Diploma & 21 & $11.2 \%$ \\
\hline & Bachelor degree & 16 & $8.6 \%$ \\
\hline & Post-graduate degree & 10 & $5.3 \%$ \\
\hline \multicolumn{4}{|c|}{ Number of children $(n=186)$} \\
\hline & No children & 14 & $7.5 \%$ \\
\hline & 1 child & 15 & $8.1 \%$ \\
\hline & 2 children & 59 & $31.7 \%$ \\
\hline & 3 children & 55 & $29.6 \%$ \\
\hline & More than 3 children & 43 & $23.1 \%$ \\
\hline \multicolumn{4}{|c|}{ Help to complete questionnaire $(n=184)$} \\
\hline & Yes & 63 & $34.2 \%$ \\
\hline & No & 121 & $65.8 \%$ \\
\hline \multicolumn{4}{|c|}{ Religion $(n=183)$} \\
\hline & No religion & 40 & $21.9 \%$ \\
\hline & Catholic & 38 & $20.8 \%$ \\
\hline & Other Christian & 104 & $56.8 \%$ \\
\hline & Other $^{\mathrm{a}}$ & 1 & $0.5 \%$ \\
\hline \multicolumn{4}{|c|}{ Importance of religious values in decision making $(n=183)$} \\
\hline & Very important & 49 & $26.8 \%$ \\
\hline & Somewhat important & 35 & $19.1 \%$ \\
\hline & Only a little important & 38 & $20.8 \%$ \\
\hline & Not at all important & 61 & $33.3 \%$ \\
\hline \multicolumn{4}{|c|}{ Net household income $(n=169)$} \\
\hline & Less than $\mathrm{A} \$ 25,000$ & 73 & $43.2 \%$ \\
\hline & $\mathrm{A} \$ 25,000$ to $\mathrm{A} \$ 50,000$ & 53 & $31.4 \%$ \\
\hline & $\mathrm{A} \$ 50,001$ to $\mathrm{A} \$ 100,000$ & 30 & $17.8 \%$ \\
\hline & More than $\mathrm{A} \$ 100,000$ & 13 & $7.7 \%$ \\
\hline \multicolumn{4}{|c|}{ Number of relatives with PD $(n=184)$} \\
\hline & 0 & 96 & $52.2 \%$ \\
\hline & 1 & 63 & $34.2 \%$ \\
\hline & 2 & 14 & $7.6 \%$ \\
\hline & 3 or more & 11 & $6.0 \%$ \\
\hline
\end{tabular}

${ }^{\mathrm{a}}$ Buddhist 
reported by $34.2 \%$ and slightly more than half saw religion as very or somewhat important.

\section{Genetic knowledge items}

The majority of respondents $(77.5 \%)$ rated their genetic knowledge as "a little" or "none" and $22.5 \%$ rated themselves as having "moderate" genetic knowledge (Table 2). While $41.0 \%$ correctly answered "genes come in pairs with one copy from

Table 2 Results of knowledge items

\begin{tabular}{|c|c|c|}
\hline & No. & Percent \\
\hline \multicolumn{3}{|c|}{ Please indicate your level of genetic knowledge } \\
\hline A lot & 0 & $0.0 \%$ \\
\hline Moderate & 42 & $22.5 \%$ \\
\hline A little & 105 & $56.1 \%$ \\
\hline None & 40 & $21.4 \%$ \\
\hline Total & 187 & \\
\hline \multicolumn{3}{|c|}{ 1. Can PD be inherited? } \\
\hline Agree $^{\mathrm{a}}$ & 54 & $29.0 \%$ \\
\hline Disagree & 24 & $12.9 \%$ \\
\hline Don’t know & 108 & $58.1 \%$ \\
\hline Total & 186 & \\
\hline \multicolumn{3}{|c|}{ 2. If one family member has PD, will all family members develop PD? } \\
\hline Agree & 4 & $2.2 \%$ \\
\hline Disagree $^{\mathrm{a}}$ & 115 & $61.8 \%$ \\
\hline Don’t know & 67 & $36.0 \%$ \\
\hline Total & 186 & \\
\hline \multicolumn{3}{|c|}{ 3. Genes come in pairs; one copy from each parent } \\
\hline Agree $^{\mathrm{a}}$ & 75 & $41.0 \%$ \\
\hline Disagree & 18 & $9.8 \%$ \\
\hline Don’t know & 90 & $49.2 \%$ \\
\hline Total & 183 & \\
\hline \multicolumn{3}{|c|}{ 4. Without genes that cause PD, can you still get PD? } \\
\hline Agree $^{\mathrm{a}}$ & 90 & $48.1 \%$ \\
\hline Disagree & 12 & $6.4 \%$ \\
\hline Don’t know & 85 & $45.5 \%$ \\
\hline Total & 187 & \\
\hline \multicolumn{3}{|c|}{ 5. Is it possible to have a PD gene but not have symptoms of PD? } \\
\hline Agree $^{\mathrm{a}}$ & 70 & $37.6 \%$ \\
\hline Disagree & 4 & $2.2 \%$ \\
\hline Don’t know & 112 & $60.2 \%$ \\
\hline Total & 186 & \\
\hline \multicolumn{3}{|c|}{ 6. A genetic test for PD is available now } \\
\hline Agree $^{\mathrm{a}}$ & 16 & $8.6 \%$ \\
\hline Disagree & 51 & $27.3 \%$ \\
\hline Don’t know & 120 & $64.2 \%$ \\
\hline Total & 187 & \\
\hline
\end{tabular}

${ }^{\mathrm{a}}$ Indicates the correct response each parent", $58.1 \%$ responded they "did not know" if PD can be inherited. The mean number of correct responses was 2.2 $(\mathrm{SD}, 1.4)$ out of the six questions and overall, $40.6 \%$ had three or more correct responses with no difference between those with or without a family history (35/92 with a family history vs $37 / 86$ without a family history; $p=0.54$ ). A total $15.6 \%$ had no correct responses. Two knowledge items (items 4 and 6 in Table 2) may be ambiguous and/or confusing, and the knowledge data were reanalyzed with these items excluded. The mean number of correct responses was 1.7 (SD, 1.1) out of the four questions and overall, $53.9 \%$ had two or more correct responses with no difference between those with or without a family history (48/98 with a family history vs $48 / 87$ without a family history; $p=0.46$ ).

Responses to the knowledge items had a low correlation with self-reported knowledge; the highest correlation was between "genes come in pairs" and self-rated knowledge $(r=0.28, p<0.001)$, and therefore self-rated genetic knowledge was a poor proxy for objective knowledge.

Attitudes towards genetic testing

The vast majority (97\%) of respondents either "agreed" or "strongly agreed" that a genetic test should be offered to people with symptoms of PD (Table 3). Predictive testing was supported by $78 \%$ of respondents whereas prenatal testing received less support with only $58 \%$ agreeing or strongly agreeing this test should be offered to pregnant mothers. However, more than $90 \%$ of respondents indicated they would personally take a genetic test for PD in the next 6 months if it was available.

The majority of respondents had favorable attitudes toward the outcomes of genetic testing. For example, $92 \%$ thought that genetic testing will help find a cure for PD, $77 \%$ reported genetic testing will help prevent PD, would allow $82 \%$ to plan for the future, $91 \%$ learn of their child's risk, $94 \%$ make them find out about new therapies, and $62 \%$ disagreed with the negative question that learning of a PD gene was of no help. The majority would not be upset finding they had a gene for PD, and slightly less than half would be concerned about their own, their partner's, or their family's reactions. Approximately half were unsure about the accuracy of the test (48\%), would be concerned about insurance issues (55\%), or concerned about employment (46\%).

Multivariate analysis

The results from the ordinal regression for diagnostic testing showed that respondents who were concerned about the accuracy of the test or who feared being upset by the test result were more likely to disagree with diagnostic testing. However, others were more likely to support diagnostic testing to learn if a child was at risk of PD or if the test was in the hope of 
Table 3 Results of the attitude items

\begin{tabular}{lcc}
\hline Ntem & Norcent \\
\hline Diagnostic test: If a blood test were to become available that would \\
accurately show whether or not an individual has inherited a \\
Parkinson's disease gene, do you think that test should be offered to \\
people with symptoms of Parkinson's disease? \\
Strongly agree & 88 & $47.1 \%$ \\
Agree & 93 & $49.7 \%$ \\
Disagree & 6 & $3.2 \%$ \\
Strongly disagree & 0 & $0.0 \%$ \\
Total & 187 & \\
Predictive test: Do you think that the blood test should be offered to \\
people without symptoms of Parkinson's disease? \\
Strongly agree & 39 & $21.0 \%$ \\
Agree & 106 & $57.0 \%$ \\
Disagree & 33 & $17.7 \%$ \\
Strongly disagree & 8 & $4.3 \%$ \\
Total & 186 & \\
Prenatal test: Do you think that a prenatal test for Parkinson's disease \\
should be offered to pregnant mothers? \\
Strongly agree & 27 & $14.8 \%$ \\
Agree & 79 & $43.4 \%$ \\
Disagree & 63 & $34.6 \%$ \\
Strongly disagree & 13 & $7.1 \%$ \\
Total & 182 & \\
Persoly &
\end{tabular}

Personal test: If a blood test were to become available in the next

6 months that would accurately show whether or not you had inherited a Parkinson's disease gene, would you want to have that test?

$\begin{array}{llr}\text { Strongly agree } & 80 & 43.2 \% \\ \text { Agree } & 90 & 48.6 \% \\ \text { Disagree } & 15 & 8.1 \% \\ \text { Strongly disagree } & 0 & 0.0 \% \\ \text { Total } & 185 & \end{array}$

Gene test find cure: Do you think genetic testing will help scientists find a cure for Parkinson's disease?

$\begin{array}{llr}\text { Strongly agree } & 76 & 41.3 \% \\ \text { Agree } & 93 & 50.5 \% \\ \text { Disagree } & 14 & 7.6 \% \\ \text { Strongly disagree } & 1 & 0.5 \% \\ \text { Total } & 184 & \end{array}$

Gene test prevent $P D$ : Do you think genetic testing will help in the prevention of Parkinson's disease?

$\begin{array}{llr}\text { Strongly agree } & 44 & 24.0 \% \\ \text { Agree } & 97 & 53.0 \% \\ \text { Disagree } & 38 & 20.8 \% \\ \text { Strongly disagree } & 4 & 2.2 \% \\ \text { Total } & 183 & \end{array}$

Plan for future: I could plan for the future

$\begin{array}{llr}\text { Strongly agree } & 42 & 22.8 \% \\ \text { Agree } & 109 & 59.2 \% \\ \text { Disagree } & 32 & 17.4 \% \\ \text { Strongly disagree } & 1 & 0.5 \% \\ \text { Total } & 184 & \end{array}$

Table 3 (continued)

\begin{tabular}{llr}
\hline Item & No. & Percent \\
\hline $\begin{array}{l}\text { Child's risk: I could learn if my children are at risk of inheritin } \\
\text { Parkinson's disease }\end{array}$ & \\
Strongly agree & 64 & $35.6 \%$ \\
Agree & 99 & $55.0 \%$ \\
Disagree & 16 & $8.9 \%$ \\
Strongly disagree & 1 & $0.6 \%$ \\
Total & 180 &
\end{tabular}

Have gene, seek therapies: A test showing that I had a gene for Parkinson's disease would make me more likely to find out about new therapies and treatments for Parkinson's disease

$\begin{array}{llr}\text { Strongly agree } & 71 & 38.4 \% \\ \text { Agree } & 103 & 55.7 \% \\ \text { Disagree } & 9 & 4.9 \% \\ \text { Strongly disagree } & 2 & 1.1 \% \\ \text { Total } & 185 & \end{array}$

No help: Treatment and prevention options for Parkinson's disease are limited, so learning I had a gene for Parkinson's disease wouldn't help much

$\begin{array}{llr}\text { Strongly agree } & 6 & 3.3 \% \\ \text { Agree } & 64 & 35.0 \% \\ \text { Disagree } & 85 & 46.4 \% \\ \text { Strongly disagree } & 28 & 15.3 \% \\ \text { Total } & 183 & \end{array}$

Gene upsetting: It would be too upsetting to learn I have a gene for Parkinson's disease, so I am happier not knowing

$\begin{array}{llr}\text { Strongly agree } & 4 & 2.2 \% \\ \text { Agree } & 31 & 17.1 \% \\ \text { Disagree } & 98 & 54.1 \% \\ \text { Strongly disagree } & 48 & 26.5 \% \\ \text { Total } & 181 & \end{array}$

Own reactions: I would be concerned about my emotional reactions

$\begin{array}{llr}\text { Strongly agree } & 10 & 5.5 \% \\ \text { Agree } & 80 & 43.7 \% \\ \text { Disagree } & 73 & 39.9 \% \\ \text { Strongly disagree } & 20 & 10.9 \% \\ \text { Total } & 183 & \end{array}$

Partner's reaction: I would be concerned about my partner's reaction

$\begin{array}{llr}\text { Strongly agree } & 10 & 5.7 \% \\ \text { Agree } & 67 & 38.1 \% \\ \text { Disagree } & 76 & 43.2 \% \\ \text { Strongly disagree } & 23 & 13.1 \% \\ \text { Total } & 176 & \end{array}$

Family's reaction: I would be concerned about my family's reaction

$\begin{array}{llr}\text { Strongly agree } & 10 & 5.6 \% \\ \text { Agree } & 74 & 41.1 \% \\ \text { Disagree } & 78 & 43.3 \% \\ \text { Strongly disagree } & 18 & 10.0 \% \\ \text { Total } & 180 & \end{array}$


Table 3 (continued)

\begin{tabular}{lcc}
\hline Item & No. & Percent \\
\hline Test accuracy: I would not be sure if the test is accurate \\
Strongly agree & 4 & $2.2 \%$ \\
Agree & 84 & $46.4 \%$ \\
Disagree & 83 & $45.9 \%$ \\
Strongly disagree & 10 & $5.5 \%$ \\
Total & 181 & \\
Insurance worries: I would worry about how it would affect my health \\
and/or life insurance & & \\
Strongly agree & 17 & $9.3 \%$ \\
Agree & 83 & $45.6 \%$ \\
Disagree & 69 & $37.9 \%$ \\
Strongly disagree & 13 & $7.1 \%$ \\
Total & 182 & \\
Job worries: I would worry that it would affect my chances of finding a \\
job & & \\
Strongly agree & 17 & $10.1 \%$ \\
Agree & 61 & $36.3 \%$ \\
Disagree & 80 & $47.6 \%$ \\
Strongly disagree & 10 & $6.0 \%$ \\
Total & 168 & \\
\hline
\end{tabular}

finding a cure for PD. These factors (except concern about test accuracy) were also significantly associated with support for predictive testing. In addition, it was found that persons with higher education were more likely to disagree with testing.

Distinct determinants for the other two genetic outcome variables were identified. Regarding support for prenatal testing, persons who place high importance on religious values and worry about insurance were more likely to disagree with testing whereas those who had hope for preventing PD, plan for future, and learning if the child was at risk were more likely to agree with testing. For personal genetic testing, persons with fear of being upset by the result were more likely to disagree with testing whereas seeking therapies, learning if the child was at risk, needed help with completing the questionnaire, and concerns about no symptoms PD were more likely to agree with testing.

\section{Discussion}

This study demonstrates that in a sample of patients with PD, there is overwhelming support for diagnostic testing for PD, and the majority supported predictive testing, and fewer supported prenatal testing. Interestingly, a minority who supported diagnostic testing would not undertake a diagnostic test themselves. The percentages supporting diagnostic testing for PD $(97 \%)$ and interested in undertaking a diagnostic test themselves $(90 \%)$ were greater than those reported elsewhere; for example in a demographically similar (other than more educated) and clinically similar group of participants with PD, $86 \%$ thought genetic testing for PD would be useful and $59 \%$ of participants were interested in genetic testing for themselves (Falcone et al. 2011). However, open-ended questions to elicit attitudes towards genetic testing in that study (Falcone et al. 2011) were quite different to the multi-choice options and the description and purpose of genetic testing given in the present study. Therefore, framing of questions may have an important role in responses.

The multivariate analysis showed that genetic knowledge had little bearing on attitudes. This was not surprising given the levels of genetic knowledge in the sample. Morren et al (2007) and Jallinoja and Aro (2000) reported that high levels of knowledge were positively associated with favorable attitudes towards genetic testing, whereas Tan et al. (2007) found no significant associations between these factors in North Americans affected with PD (or their carers). The present study had similar findings to Tan et al. (2007); moreover, this study and Tan et al.'s study are comparable as they both had similar study designs, and used the same knowledge items, and the North American sample of PD affected people had similar characteristics to this study. Tan et al. reported $31 \%$ as having $\geq 3 / 6$ knowledge items correct whereas this study had $40.6 \% \geq 3 / 6$ knowledge items correct (or $53.9 \% \geq 2 / 4$ correct when the two ambiguous items were removed).

The key factors associated with supporting testing can be summarized as to find a cure (prevent PD with prenatal testing and seeking therapies with a personal test) and to learn of their child's risk for developing PD. These factors were statistically significant across all four testing scenarios. The hope of finding a cure is reflected in other studies as the most important benefit from testing. For example, using open-ended questions in a group of 168 people with $\mathrm{PD}$, the leading reported perceived benefits of genetic testing were to discover better treatments and prevention (27\%), and to discover a cure (26\%) (Falcone et al. 2011). Interestingly, learning of risks to a family member was identified as a concern for participants in the Falcone et al. study (Falcone et al. 2011) whereas in this study this was seen as a positive factor. This difference is likely to be due to framing of the question and the approach to eliciting responses (i.e., open-ended opposed to multichoice in the present study). A key difference between the study samples appears to be that participants in the Falcone et al. study had an apparent relatively higher level of genetic knowledge as the majority correctly answered questions addressing concepts related to risk factor genes, penetrance, and familial risk for PD (Falcone et al. 2011) whereas in the present study, the mean correct responses to knowledge questions was $37 \%(2.2 / 6)$ (or $43 \%(1.7 / 4)$ excluding two ambiguous questions). In addition, $50 \%$ of those in the present study reported that their highest level of education was high school or less whereas the corresponding value in the Falcone study was $12 \%$ (Falcone et al. 2011). 
The factors that were associated with negative attitudes towards testing were, generally, the fear of being upset to learn they have a gene for Parkinson's disease and concerns about the test accuracy. Nevertheless, only 3, 22, 42, and $8 \%$ disagreed with diagnostic, predictive, prenatal, or having a test themselves, respectively. Thus, the potential adverse effects from genetic testing were of minor importance for this sample. Moreover, many participants believed genetic testing would help advance scientific knowledge of PD and possibly lead to better treatments, a cure, and/or prevention. The potential to find a cure for PD and to inform a child of their risk were of utmost importance across all four options of genetic testing.

In the present study, the level of education did not appear to have any impact on attitudes towards diagnostic, predictive, or undergoing a personal genetic test; that is, different education levels were not associated with more favorable or less favorable attitudes towards genetic testing or its consequences. However, higher levels of education were associated with slightly less support for prenatal testing. Previous studies have shown that people with higher levels of education tend to be more enthusiastic about testing (Jallinoja and Aro 2000; Dahodwala et al. 2007) but are also more concerned about the consequences of genetic testing; (Aro et al. 1997) this duality was noted by Tan et al. in their Asian PD sample but not their North American sample (Tan et al. 2007). Our study identified that those with high genetic knowledge were more likely to have higher levels of education; this may confound the association between genetic knowledge and attitudes towards genetic testing. Nevertheless, the associations between attitudes and genetic knowledge were similar across both our samples and were similar to the results reported by Tan et al. for their North American sample (Tan et al. 2007).

The importance of religious values for decision-making was inversely associated with support for prenatal testing. This factor was independent of the religion the participant stated they "belonged" to (religion was not significantly associated with any knowledge or attitude items). It is commonly reported that those who place greater importance on religious values are more likely to refuse prenatal genetic testing (Anderson 2009). For example, a large study of pregnant women in California showed that those who rated religious values as highly important were substantially less likely to have a prenatal genetic test; this result was independent of the religion they belonged to (Press and Browner 1998). The most common fundamental issue for religion and prenatal testing involves prohibition against termination of pregnancy (Weil 2000). For some patients, religious beliefs strengthen or support decisions to avoid test procedures which may lead to termination of pregnancy (Weil 2000). However, in this study, the participants were affected with PD and were highly unlikely to have additional children, and unlikely to undergo prenatal testing. Therefore, their attitudes to prenatal testing may be a projection of their personal values to society. This includes the notions that genetic predispositions may be the will of God (Fanning and Clayton 2009), and that the symptoms of PD generally do not present themselves until later in life.

It was thought that those with highly important religious values may be more skeptical and less likely to support genetic testing. This study failed to identify any association between the importance of religious values and diagnostic or predictive genetic testing or willingness to undertake testing. Unlike prenatal testing, where there is a possibility that the test result may lead to the termination of a pregnancy and conflict with their religious beliefs, diagnostic and predictive testing may allow those with highly important religious beliefs to reduce uncertainty by providing a genetic diagnosis, plan for the future, and pass information on to their offspring without compromising their religious beliefs. Thus, it is likely that knowledge from some forms of genetic testing may be more acceptable and provide benefits independent of any religious paradigm. There is relatively little literature on the importance, strength, or "intensity" of religious values on acceptability genetic testing, and most studies only go as far as asking spiritual faith or religion (Schwartz et al. 2000; Usta et al. 2010). Within religions, there is wide variation in the interpretation and participation in ceremonies and practices (Greb et al. 1988). Some people and groups may be conservative, fundamental, or literal about their spiritual faith and others may be very liberal. The importance of religious values in decision-making requires more understanding to assist patients during genetic counseling (Table 4).

Although the value of genetic testing in PD is unclear, the increasing identification of PD genes and subsequent development of genetic tests for PD may, in time, lead to interest in genetic counseling and risk prediction for PD. Currently, the greatest value of genetic testing lies in testing patients with juvenile or early onset PD and in families who show Mendelian inheritance patterns (Dekker et al. 2003). Nevertheless, the results from this study have some implications for genetic counseling. To assist individuals to make informed personal or medical decisions, the genetic counselor should recognize that, in general, people have little genetic knowledge and accordingly convey information to clients in terms that are easily understood. However, the level of genetic knowledge in this sample may have little bearing on attitudes toward genetic testing. In fact, other studies have found that those who are naïve have favorable attitudes toward testing and are generally unaware of the potential negative consequences of genetic testing (Tan et al. 2007; Moscarillo et al. 2007). Furthermore, self-rated genetic knowledge was a very poor predictor of objective knowledge. Accordingly, a genetic counselor may need to explore the depth of understanding of genetics a client may have and then identify and correct any 
Table 4 Predictors for attitudes (multivariate)

\begin{tabular}{|c|c|c|}
\hline Predictor & Coefficient $^{\mathrm{a}}$ & $p$ value \\
\hline \multicolumn{3}{|l|}{ Diagnostic testing } \\
\hline Constant (DiagTest $=$ strongly agree) & 1.307 & 0.338 \\
\hline Constant $($ DiagTest $=$ agree $)$ & 5.316 & $<0.001^{\mathrm{b}}$ \\
\hline Family PD (1 vs 0$)$ & 0.434 & 0.085 \\
\hline Upsetting to self (inc. agreement) & -0.564 & $0.002^{\mathrm{t}}$ \\
\hline Find cure (inc. agreement) & 0.745 & $<0.001^{\mathrm{t}}$ \\
\hline Child's risk (inc. agreement) & 0.439 & $0.038^{\mathrm{t}}$ \\
\hline Test accuracy (inc. agreement) & -0.416 & $0.042^{\mathrm{b}}$ \\
\hline Age & -0.022 & 0.106 \\
\hline \multicolumn{3}{|l|}{$R^{2}=27.8 \%$} \\
\hline \multicolumn{3}{|l|}{ Predictive testing } \\
\hline Constant (PredicTest $=$ strongly agree $)$ & -0.190 & 0.758 \\
\hline Constant $($ PredicTest $=$ agree $)$ & 1.944 & $0.002^{\mathrm{b}}$ \\
\hline Constant $($ PredicTest $=$ disagree $)$ & 3.731 & $<0.001^{\mathrm{b}}$ \\
\hline Upsetting to self (inc. agreement) & -0.322 & $0.039^{\mathrm{t}}$ \\
\hline Find cure (inc. agreement) & 0.379 & $0.021^{\mathrm{b}}$ \\
\hline Child's risk (inc. agreement) & 0.356 & $0.038^{\mathrm{b}}$ \\
\hline Partner's reaction (inc. agreement) & -0.198 & 0.156 \\
\hline Education (higher education) & -0.149 & $0.030^{\mathrm{t}}$ \\
\hline \multicolumn{3}{|l|}{$R^{2}=17.9 \%$} \\
\hline \multicolumn{3}{|l|}{ Prenatal testing } \\
\hline Constant (PrenatalTest=strongly agree) & 0.166 & 0.730 \\
\hline Constant $($ PrenatalTest $=$ agree $)$ & 1.718 & $0.001^{\mathrm{b}}$ \\
\hline Constant $($ PrenatalTest $=$ disagree $)$ & 3.670 & $<0.001^{\mathrm{b}}$ \\
\hline Prevent PD (inc. agreement) & 0.328 & $0.013^{\mathrm{t}}$ \\
\hline Plan future (inc. agreement) & 0.505 & $0.003^{\mathrm{t}}$ \\
\hline Child's risk (inc. agreement) & 0.363 & $0.036^{\mathrm{t}}$ \\
\hline Insurance worries (inc. agreement) & -0.304 & $0.021^{\mathrm{b}}$ \\
\hline Religious importance (inc. importance) & -0.221 & $0.005^{\mathrm{t}}$ \\
\hline \multicolumn{3}{|l|}{$R^{2}=24.2 \%$} \\
\hline \multicolumn{3}{|l|}{ Personal test } \\
\hline Constant $($ PersonalTest $=$ strongly agree $)$ & 0.413 & 0.649 \\
\hline Constant $($ PersonalTest $=$ agree $)$ & 3.907 & $<0.001^{\mathrm{b}}$ \\
\hline Symptoms, no gene ( 1 vs 0 ) & 0.541 & $0.039^{\mathrm{b}}$ \\
\hline Upsetting to self (inc. agreement) & -0.982 & $<0.001^{\mathrm{b}}$ \\
\hline Prevent PD (inc. agreement) & 0.317 & 0.088 \\
\hline Child's risk (inc. agreement) & 0.946 & $<0.001^{\mathrm{b}}$ \\
\hline Seek therapies (inc. agreement) & 0.992 & $<0.001^{\mathrm{b}}$ \\
\hline Test accuracy (inc. agreement) & -0.344 & 0.118 \\
\hline Help with Q's (1 vs 2) & 0.638 & $0.017^{\mathrm{b}}$ \\
\hline$R^{2}=43.9 \%$ & & \\
\hline
\end{tabular}

${ }^{a}$ Positive coefficients indicate greater support for the test and negative coefficients indicate less support for the test

${ }^{\mathrm{b}}$ Significant at the $5 \%$ level

misinformation based on possible preconceived ideas and ensure the individual is in a position to make an informed decision.
Study limitations

This study was undertaken in a sample of those with clinically diagnosed PD who had previously agreed to participate in research. Thus, their views may not be representative of all the PD community. Nevertheless, the overall response rate was $69 \%$ and therefore this sample is likely to be representative of those who agree to participate in research. Moreover, all participants were recruited by mail surveys and avoids any bias of recruiting during clinic consultations.

A second limitation was the reporting of relatives affected with PD. This study purposely selected all those in the QPP database with a family history of PD to compare attitudes to those without a family history. Of the participants, $48 \%$ reported they had one or more relative affected with PD. No difference between those with and without a family history of PD was identified in this study. However, it was not known whether the affected relative was a first-, second-, or thirddegree relative. Those with a first-degree relative are likely to have first-hand experience of the progression of $\mathrm{PD}$, and may be much more likely to support any testing for diagnosis or prediction of PD.

There were several limitations with the questionnaire used, including some of the knowledge items and the omission of two important factors. The knowledge item "A genetic test to determine whether or not one has a genetic form of Parkinson's disease is available right now?" has an ambiguous correct response as there are genetic tests available for PD but these tests are not relevant for the vast majority of people with PD. The second knowledge item "Without genes that cause PD, can you still get PD?" is potentially confusing and also has an ambiguous correct response. That is, it is likely that some genes play a role in the development of PD in the vast majority of cases. These items were taken directly from Tan et al. (2007); however, we suggest that these items are modified or replaced with more informative knowledge items in future studies. The two omissions from the questionnaire included an item to identify if the patient had early-onset PD and the years of symptoms of PD. Early-onset PD is more likely to be monogenic and therefore more amenable to genetic testing (e.g., for mutations in the LRRK2 gene) (Ishihara et al. 2007). Years of symptoms of PD, or modified to years since diagnosis of PD, may still be problematic but may be indicative of the stage of disease. We included an item on whether the participant required assistance to complete the questionnaire, and $34 \%$ responded they required help. This is a proxy for disease stage and/or severity; however, a more quantitative question might be around duration of disease. Nevertheless, we would still recommend including this item on requiring assistance as there is considerable variation in disease progression as well as the point in the disease when a diagnosis is made.

Finally, and in addition to the previous point that $34 \%$ reported they required assistance with completing the 
questionnaire, the degree of assistance is unknown and may have ranged from completing occasional free text fields to reading the question, interpreting responses, and ticking the appropriate box. Thus, the responses may be more reflective of the assistant rather than the participant. This factor was only significant in the multivariate analysis for undertaking a personal test, and therefore it may be possible that for some participants it was the assistant who desired the participant to have a confirmatory genetic diagnosis.

\section{Conclusions}

Patients with PD have a high level of interest in genetic testing for themselves, strong support for diagnostic testing, and lower levels of support for predictive and prenatal testing. Their preferences were not significantly associated with their level of genetic knowledge. The strength of their religious values was important for prenatal testing. This study provides the basis to guide the development of specific genetic counseling protocols for
$\mathrm{PD}$, and potentially other neuro-genetic diseases where informed decision-making around genetic testing may be required.

Acknowledgments The authors are thankful to Dr Gary Allen for his helpful advice on the process to recruit participants and the ethical implications. We thank the co-investigators of the Queensland Parkinson's Project, particularly Prof Peter Silburn, and the QPP study participants.

Full financial disclosures in the past year (regardless of relationship to current manuscript) This research received some funding from the School of Biomedical Sciences, Griffith University to mail out the questionnaires.

TS: was employed by Genetic Health Queensland

AM: has no relevant financial disclosures

$\mathrm{S}-\mathrm{KN}$ : has no relevant financial disclosures

GM: has no relevant financial disclosures

Compliance with ethics The study was approved by the Griffith University Human Research Ethics Committee (protocol number BPS/06/ 08/HREC), and complies with Australian laws and guidelines for conducting human research.

\section{Appendix}

Table 5 Univariate analysis for predictors of genetic testing attitudes

\begin{tabular}{|c|c|c|c|c|c|c|c|c|}
\hline \multirow[b]{2}{*}{ Predictor } & \multicolumn{2}{|c|}{ Diagnostic testing } & \multicolumn{2}{|c|}{ Predictive testing } & \multicolumn{2}{|c|}{ Prenatal testing } & \multicolumn{2}{|l|}{ Personal test } \\
\hline & Coefficient $^{\mathrm{a}}$ & $p$ value & Coefficient & $p$ value & Coefficient & $p$ value & Coefficient & $p$ value \\
\hline \multicolumn{9}{|l|}{ Knowledge factors } \\
\hline Inherit PD (1 vs 0$)$ & 0.362 & 0.129 & 0.112 & 0.560 & -0.079 & 0.668 & 0.162 & 0.470 \\
\hline Family PD (1 vs 0 ) & 0.587 & $0.005^{\mathrm{b}}$ & 0.027 & 0.879 & -0.202 & 0.247 & 0.247 & 0.222 \\
\hline Genes in pairs ( 1 vs 0 ) & 0.243 & 0.257 & 0.067 & 0.708 & -0.063 & 0.715 & 0.271 & 0.195 \\
\hline Get PD without gene ( 1 vs 0 ) & 0.082 & 0.691 & -0.187 & 0.283 & 0.026 & 0.877 & -0.024 & 0.903 \\
\hline Symptoms, no gene ( 1 vs 0 ) & 0.341 & 0.119 & 0.016 & 0.929 & 0.084 & 0.628 & 0.466 & $0.030^{\mathrm{b}}$ \\
\hline Test available ( 1 vs 0 ) & 0.443 & 0.287 & -0.239 & 0.433 & -0.218 & 0.469 & 0.362 & 0.353 \\
\hline \multicolumn{9}{|l|}{ Demographics } \\
\hline Help with Q's (1 vs 2) & 0.302 & 0.181 & 0.054 & 0.769 & -0.206 & 0.245 & 0.481 & $0.032^{\mathrm{b}}$ \\
\hline Religion (yes vs no) & -0.161 & 0.536 & -0.052 & 0.809 & -0.366 & 0.081 & -0.069 & 0.778 \\
\hline Religious importance (inc. importance) & -0.086 & 0.321 & -0.090 & 0.219 & -0.248 & $0.001^{\mathrm{b}}$ & -0.134 & 0.112 \\
\hline Education (higher education) & -0.060 & 0.389 & -0.153 & $0.011^{\mathrm{b}}$ & -0.067 & 0.245 & -0.107 & 0.113 \\
\hline Married (vs other) & 0.302 & 0.228 & 0.292 & 0.183 & 0.335 & 0.120 & -0.123 & 0.635 \\
\hline Gender (female vs male) & -0.099 & 0.637 & -0.229 & 0.200 & -0.270 & 0.116 & 0.195 & 0.349 \\
\hline Income & 0.053 & 0.644 & -0.158 & 0.100 & -0.042 & 0.643 & -0.017 & 0.878 \\
\hline Age & -0.025 & $0.041^{\mathrm{b}}$ & 0.009 & 0.373 & -0.004 & 0.716 & -0.015 & 0.200 \\
\hline \multicolumn{9}{|l|}{ Attitudes (reference $=$ strongly disagree $)$} \\
\hline Find cure & 0.639 & $<0.001^{\mathrm{b}}$ & 0.586 & $<0.001^{\mathrm{b}}$ & 0.259 & 0.052 & 0.574 & $<0.001^{\mathrm{b}}$ \\
\hline Prevent PD & 0.246 & 0.082 & 0.222 & 0.066 & 0.291 & $0.013^{\mathrm{b}}$ & 0.346 & $0.012^{\mathrm{b}}$ \\
\hline Plan future & 0.525 & $0.001^{\mathrm{b}}$ & 0.281 & $0.040^{\mathrm{b}}$ & 0.585 & $<0.001^{\mathrm{b}}$ & 0.809 & $<0.001^{\mathrm{b}}$ \\
\hline Child's risk & 0.611 & $<0.001^{\mathrm{b}}$ & 0.636 & $<0.001^{\mathrm{b}}$ & 0.673 & $<0.001^{\mathrm{b}}$ & 0.899 & $<0.001^{\mathrm{b}}$ \\
\hline
\end{tabular}


Table 5 (continued)

\begin{tabular}{lcrrrrrrr}
\hline & \multicolumn{2}{l}{ Diagnostic testing } & \multicolumn{2}{l}{ Predictive testing } & Prenatal testing & Personal test \\
\hline Seek therapies & 0.595 & $0.001^{\mathrm{b}}$ & 0.526 & $<0.001^{\mathrm{b}}$ & 0.326 & $0.018^{\mathrm{b}}$ & 0.762 & $<0.001^{\mathrm{b}}$ \\
No Help & -0.446 & $0.002^{\mathrm{b}}$ & -0.333 & $0.006^{\mathrm{b}}$ & -0.410 & $<0.001^{\mathrm{b}}$ & -0.551 & $<0.001^{\mathrm{b}}$ \\
Upsetting to self & -0.796 & $<0.001^{\mathrm{b}}$ & -0.449 & $<0.001^{\mathrm{b}}$ & -0.280 & $0.018^{\mathrm{b}}$ & -0.800 & $<0.001^{\mathrm{b}}$ \\
Own reaction & -0.404 & $0.005^{\mathrm{b}}$ & -0.259 & $0.028^{\mathrm{b}}$ & -0.095 & 0.391 & -0.326 & $0.017^{\mathrm{b}}$ \\
Partner's reaction & -0.199 & 0.151 & -0.241 & $0.040^{\mathrm{b}}$ & -0.224 & $0.047^{\mathrm{b}}$ & -0.173 & 0.197 \\
Family's reaction & -0.183 & 0.199 & -0.193 & 0.108 & -0.254 & $0.030^{\mathrm{b}}$ & -0.123 & 0.374 \\
Test accuracy & -0.646 & $<0.001^{\mathrm{b}}$ & -0.168 & 0.230 & -0.024 & 0.858 & -0.427 & $0.010^{\mathrm{b}}$ \\
Insurance worries & -0.246 & 0.078 & -0.114 & 0.328 & -0.308 & $0.008^{\mathrm{b}}$ & -0.135 & 0.311 \\
Job worries & -0.079 & 0.577 & -0.020 & 0.870 & -0.162 & 0.170 & 0.040 & 0.775 \\
\hline
\end{tabular}

${ }^{\text {a }}$ Positive coefficients indicate greater support for the test and negative coefficients indicate less support for the test

${ }^{\mathrm{b}}$ Significant at the $5 \%$ level

\section{References}

Anderson R (2009) Religious traditions and prenatal genetic counseling. Am J Med Genet C: Semin Med Genet 151C:52-61

Aro AR et al (1997) Acceptance of genetic testing in a general population: age, education and gender differences. Patient Educ Couns 32:4149

Australian Institute of Health and Welfare (2008) Indicators for chronic diseases and their determinants 2008. AIHW, Canberra

Autere J, Moilanen J, Myllyla V, Majamaa K (2000) Familial aggregation of Parkinson's disease in a Finnish population. J Neurol Neurosurg Psychiatry 69:107-109

Brant R (1990) Assessing proportionality in the proportional odds model for ordinal logistic regression. Biometrics 46:1171-78

Dahodwala N et al (2007) Interest in predictive testing for Parkinson's disease: impact of neuroprotective therapy. Parkinsonism Relat Disord 13:495-499

de Lau LML, Breteler MMB (2006) Epidemiology of Parkinson's disease. Lancet Neurol 5:525-35

Dekker M, Bonifati V, van Duijn C (2003) Parkinson's disease: piecing together a genetic jigsaw. Brain 126:1722-1733

Evers-Kiebooms G, Cassiman J, van den Berghe H (1987) Attitudes towards predictive testing in Huntington's disease: a recent survey in Belgium. J Med Genet 24:275-9

Falcone D, McCarty Wood E, Xie S, Siderowf A, van Deerlin V (2011) Genetic testing and Parkinson disease: assessment of patient knowledge, attitudes, and interest. J Genet Couns 20:384-95

Fanning J, Clayton E (2009) Religious and spiritual issues in medical genetics. Am J Med Genet C: Semin Med Genet 151C:1-5

Folstein M, Folstein S, McHugh P (1975) "Mini-Mental State" a practical method for grading the cognitive state of patients for the clinician. J Psychiatr Res 12:189-198

Greb, A. Multiculturalism and the practice of genetic counseling. in $a$ guide to genetic counseling (eds. Baker, D., Schuette, J. \& HUhlmann, W.) (Wiley-Liss Inc., New York, 1988).

IBM SPSS for Windows v20. Release 20.0.0. (SPSS Inc., Chicago, 2011).

Ishihara L et al (2007) Screening for Lrrk2 G2019S and clinical comparison of Tunisian and North American Caucasian Parkinson's disease families. Mov Disord 22:55-61
Jallinoja P, Aro AR (2000) Does knowledge make a difference? The association between knowledge about genes and attitudes toward gene tests. J Heal Commun 5:29-39

Lerman C, Seay J, Balshen A, Audrain J (1995) Interest in genetic testing among first-degree relatives of breast cancer patients. Am J Med Genet 57:385-392

Mastromauro C, Myers R, Berkman B (1987) Attitudes toward presymptomatic testing in Huntington disease. Am J Med Genet 26:271-82

Mellick GD, Siebert GA, Funayama M, Buchanan DD, Li Y, Imamichi Y, Yoshino H, Silburn PA, Hattori N (2009) Screening PARK genes for mutations in early-onset Parkinson's disease patients from Queensland, Australia. Parkinsonism Relat Disord 15(2):105-109

Morren M, Rijken M, Baanders AN, Bensing J (2007) Perceived genetic knowledge, attitudes towards genetic testing, and the relationship between these among patients with a chronic disease. Patient Educ Couns 65:197-204

Moscarillo TJ et al (2007) Knowledge of and attitudes about Alzheimer disease genetics: report of a pilot survey and two focus groups. Community Genetics 10:97-102

Norušis M (2012) IBM SPSS statistics 19 advanced statistical procedures companion. Pearson Education, Chicago

Pankratz N, Foroud T (2007) Genetics of Parkinson disease. Genetics in Medicine 9:801-811

Peters CM, Gartner CE, Silburn PA, Mellick GD (2006) Prevalence of Parkinson's disease in metropolitan and rural Queensland: a general practice survey. J Clin Neurosci 13:343-348

Press N, Browner C (1998) Characteristics of women who refuse an offer of prenatal diagnosis: data from the California maternal serum alpha fetoprotein blood test experience. Am J Med Genet 78:433-445

Quaid, K.A. Attitudes towards genetic testing for Huntington's disease in PHAROS participants. Journal of Neurology Neurosurgery and Psychiatry 76 (2005).

Quaid KA, Brandt J, Faden RR, Folstein SE (1989) Knowledge, attitude, and the decision to be tested for Huntington's disease. Clin Genet 36:431-8

Schwartz M et al (2000) Spiritual faith and genetic testing decisions among high-risk breast cancer probands. Cancer Epidemiol Biomarkers Prev 9:381-385

Sellbach AN, Boyle RS, Silburn PA, Mellick GD (2006) Parkinson's disease and family history. Parkinsonism Relat Disord 12:399-409 
Sutherland G et al (2009) Do polymorphisms in the familial Parkinsonism genes contribute to risk for sporadic Parkinson's disease? Mov Disord 24:833-838

Sveinbjornsdottir S et al (2000) Familial aggregation of Parkinson's disease in Iceland. N Engl J Med 343:1765-1770

Tan E-K et al (2007) Comparing knowledge and attitudes towards genetic testing in Parkinson's disease in an American and Asian population. J Neurol Sci 252:113-120
Usta I, Nassar A, Abu-Musa A, Hannoun A (2010) Effect of religion on the attitude of primiparous women toward genetic testing. Prenat Diagn 30:241-246

von Campenhausen S et al (2005) Prevalence and incidence of Parkinson's disease in Europe. Eur Neuropsychopharmacol 15: $473-90$

Weil J (2000) Psychosocial genetic counseling. Oxford University Press, Oxford 